\title{
Resolving conflicts in European fundamental rights protection
}

Citation for published version (APA):

Imamovic, S. (2018). Resolving conflicts in European fundamental rights protection: National and European courts' perspectives. [Doctoral Thesis, Maastricht University, Universiteit Hasselt]. Maastricht University. https://doi.org/10.26481/dis.20181212si

Document status and date:

Published: 01/01/2018

DOI:

10.26481/dis.20181212si

Document Version:

Publisher's PDF, also known as Version of record

\section{Please check the document version of this publication:}

- A submitted manuscript is the version of the article upon submission and before peer-review. There can be important differences between the submitted version and the official published version of record.

People interested in the research are advised to contact the author for the final version of the publication, or visit the DOI to the publisher's website.

- The final author version and the galley proof are versions of the publication after peer review.

- The final published version features the final layout of the paper including the volume, issue and page numbers.

Link to publication

\footnotetext{
General rights rights.

- You may freely distribute the URL identifying the publication in the public portal. please follow below link for the End User Agreement:

www.umlib.nl/taverne-license

Take down policy

If you believe that this document breaches copyright please contact us at:

repository@maastrichtuniversity.nl

providing details and we will investigate your claim.
}

Copyright and moral rights for the publications made accessible in the public portal are retained by the authors and/or other copyright owners and it is a condition of accessing publications that users recognise and abide by the legal requirements associated with these

- Users may download and print one copy of any publication from the public portal for the purpose of private study or research.

- You may not further distribute the material or use it for any profit-making activity or commercial gain

If the publication is distributed under the terms of Article $25 \mathrm{fa}$ of the Dutch Copyright Act, indicated by the "Taverne" license above, 


\section{Summary}

The legal architecture of European fundamental rights has become complex. This complexity is caused by the co-existence of at least three legal systems, each with their catalogue of fundamental rights and their own enforcement system. At the national level, fundamental rights are mainly to be found in constitutions, sometimes complemented by international treaties, and, in some cases also EU law. Secondly, at the international level, individuals can bring individual complaints before the ECtHR, alleging violations of their fundamental rights as protected by the ECHR. Thirdly, fundamental rights are also protected in the context of EU law, where they derive from the Charter, common traditions and the ECHR. Legal action based on the infringement of EU fundamental rights may involve the CJEU as well as national courts.

The legal relationships between these component parts of the European human rights architecture and between the actors belonging to each of these systems are contested and are still evolving. Recently, the most important catalyst for change in the context of the EU is the entry into force of the Lisbon Treaty. This Treaty gives the EU a binding Charter of Fundamental Rights and obliges the EU to accede to the ECHR, necessitating a new conception of the relationship between the CJEU and the ECtHR.

The increased focus on fundamental rights in the European space poses multiple political and legal challenges for the EU as well as for its Member State courts. It is particularly problematic for national courts, since they are at the crossroads between three legal systems: as state organs, they must uphold national Constitution while, at the same time, ensuring compliance of their state with the ECHR and with EU law and EU fundamental rights. Consequently, national courts may be confronted with competing and conflicting obligations for the protection of fundamental rights. After all, the catalogues may not require the same level of protection and are interpreted by different highest courts, while clear rules governing their mutual relationship are lacking. 
This book examines different ways for national courts to deal with and overcome conflicts between EU and ECHR law. It starts with a discussion on the role and place of fundamental rights in the EU, showing how and why the EU, having become a human rights actor in its own right, is different from other more natural human rights actors in Europe, such as the ECHR and the national constitutional systems (Chapter 1 ). It then analyses the relationships between the different actors in order to understand how they relate to each other exactly and how the system works as a whole (Chapter 2 ). The analysis has shown that the CJEU and the ECtHR have been engaging in various types of judicial dialogue over the years, most notably by citing each other's case law, and they have generally managed to avoid conflicts that could arise as a consequence of the divergent interpretation and application of fundamental rights. While the Courts have certainly done a good job overall, the risk of divergences continues to exist because of the lack of a formal mechanism between the Strasbourg and Luxembourg courts, and the more recent developments have borne this out.

The narrative in the second part of the book focuses on the tensions, divergences and conflicts between EU and ECHR law and the case law of the Luxembourg and Strasbourg courts in the post-Treaty of Lisbon period. Chapter 3 first explores the new state of affairs in order to grasp, in particular, the impact that the new institutional setting has had on the relationship between the CJEU and the ECtHR. It takes a more systematic approach in examining the changes that have triggered the tensions, with a special focus on Opinion 2/13, before going into the substantive rulings of the two European courts. It shows that the post-Lisbon period is characterised by a number of new developments in the case law of the CJEU - most prominently the almost exclusive focus on the Charter coupled with the sharp decline in references to the ECHR and the negative Opinion 2/13 on the EU's accession to the ECHR - that have had an impact on its relationship with the Strasbourg Court, causing tension and providing grounds for more divergence. Chapters 4 and 5 identify the two areas in which the tensions have materialised, namely, the Area of Freedom, Security and Justice (AFSJ), in which mutual trust and recognition comes into play, and the field of fundamental social rights. The outcome in these two chapters is an in-depth analysis of the 
relevant case law of the Strasbourg and Luxembourg courts which points to the incompatibilities and discusses why and the extent to which they are problematic.

The centrepiece of this book is its third part, which critically explores different ways for national courts to deal with and overcome conflicts - or what they may perceive to be conflicts - between EU and ECHR law. Chapter 6 examines different rules of conflict available to national courts when trying to find a solution for a conflict between EU and ECHR law. It concludes that international law does not offer adequate rules capable of resolving conflicts between EU law and the $E C H R$, due to their special nature and status in international law. The only rules that could be used are those found in the treaties themselves. In this regard, an argument has been made that Article 52(3) of the EU Charter of Fundamental Rights, even though not written as a conflict rule, can be seen as such. Article 52(3) of the Charter states that corresponding Charter and ECHR rights shall have the same meaning and scope, while the exact meaning and scope of the Convention rights, pursuant to the explanatory notes on this provision, is not only determined by the wording of the Convention, but also by the case law of the Strasbourg Court. Therefore, when there is a conflict between EU law (which must be interpreted in light of the Charter) and the ECHR, the latter should be followed. The seventh and final chapter develops different scenarios using actual cases of national courts in order to examine ways in which national courts have dealt with the issue so far. This final chapter has a normative dimension, in that it not only discusses how national courts have dealt with conflicts but also how they should deal with what they perceive to be conflicts between their obligations under EU law and under the ECHR. The first identified scenario is national courts seeking conform interpretations. Indeed, some national courts will go to great lengths to find that the jurisprudence of the Luxembourg and Strasbourg courts is consistent and avoid the conflict altogether. However, conform interpretation can also be problematic, because national courts may present the outcome of the case as a conform interpretation, while in fact they give priority to one or to the other. The second scenario refers to situations in which national courts give priority to the $E C H R$, without sending the question to the CJEU for preliminary ruling, even though this may mean failing to comply with the EU law obligations. As a result, a State could face infringement proceedings for breaching EU law. The third 
scenario features cases in which national courts have decided to reframe the conflict between EU and ECHR law to a conflict between EU law and the national constitution, which is then interpreted in light of the ECHR. The fourth and last scenario concerns sending the questions of compatibility between EU law and the ECHR to the CJEU for a preliminary ruling to Luxembourg. This has been identified as a preferred scenario, but only when national courts actively engage in a dialogue with the CJEU, questioning the interpretation of EU law, as well as the choices of the CJEU made in that regard, and suggesting their own interpretation of the provisions of EU law in light of the Charter (which should then be interpreted in conformity with the ECHR). This should be supported by a reference to Article 52(3) of the Charter, which clearly and convincingly states that corresponding Charter and ECHR rights shall have the same meaning and scope. Hence, there should never be an incompatibility between the two sources if the rights correspond (and they do in the majority of the cases), because complying with the ECHR minimum standards, as interpreted by the ECtHR, would also mean compliance with primary law of the EU. 


\section{Samenvatting}

De juridische structuur van de Europese grondrechten is complex geworden. Deze complexiteit wordt veroorzaakt door het naast elkaar bestaan van ten minste drie rechtssystemen, elk met hun eigen grondrechtencatalogus en hun eigen handhavingssysteem. Op nationaal niveau zijn de grondrechten vooral te vinden in grondwetten, soms aangevuld met internationale verdragen en, in sommige gevallen, ook EU-wetgeving. Verder kunnen individuen op internationaal niveau individuele klachten voor het EHRM brengen, wanneer zij beweren dat hun grondrechten zoals beschermd door het EVRM zijn geschonden. Ten slotte, worden grondrechten ook beschermd in de context van EU-recht, waar ze voortvloeien uit het Handvest en gemeenschappelijke constitutionele tradities en het EVRM. De juridische verhoudingen tussen deze componenten van de Europese mensenrechtenarchitectuur en tussen de actoren die bij elk van deze systemen horen, worden betwist en evolueren nog steeds. Een cruciale katalysator voor verandering was de inwerkingtreding van het Verdrag van Lissabon. Dit Verdrag geeft de EU een bindend Handvest van de grondrechten en verplicht de EU tot het EVRM toe te treden, waardoor de onderlinge verhoudingen opnieuw tegen het licht gehouden worden.

De toegenomen aandacht voor de grondrechten in de Europese ruimte stelt zowel de EU als nationale rechters voor een aantal uitdagingen. Nationale rechters bevinden zich als het ware op het kruispunt van drie rechtsstelsels: als staatsorganen moeten zij de nationale grondwet handhaven en tegelijkertijd ervoor zorgen dat hun land voldoet aan het EVRM en aan EU-wetgeving en EUgrondrechten. Die catalogi vereisen niet altijd hetzelfde beschermingsniveau en worden door verschillende hoogste rechtbanken geïnterpreteerd, terwijl eenduidige regels voor hun onderlinge verhoudingen ontbreken. Bijgevolg kunnen nationale rechters worden geconfronteerd met tegenstrijdige verplichtingen ter bescherming van de grondrechten.

Dit boek analyseeert dergelijke conflicten tussen EU- en EVRM-recht en onderzoekt manieren om ze op te lossen. Het onderzoek begint met een discussie 
over de rol en plaats van grondrechten in de EU, die laat zien hoe en waarom de EU een mensenrechtenactor is geworden, maar van een ander karakter dan bestaande traditionele mensenrechtenactoren in Europa, zoals het EVRM en de nationale constitutionele actoren (hoofdstuk 1 ). Vervolgens analyseert het de relaties tussen de verschillende actoren om goed inzicht te krijgen in hun onderlinge verhoudingen en in de manier waarop het systeem werkt als geheel (hoofdstuk 2). Uit de analyse blijkt dat het HvJEU en het EHRM in de loop der jaren verschillende vormen van rechterlijke dialoog hebben gevoerd, met name door te verwijzen naar elkaars jurisprudentie, en dat zij er over het algemeen in geslaagd zijn conflicten die konden ontstaan als gevolg van uiteenlopende interpretaties en de toepassing van fundamentele rechten te voorkomen. Toch blijft het risico van verschillen bestaan vanwege het ontbreken van een formeel mechanisme tussen de rechtbanken in Straatsburg en Luxemburg, en een aantal recente ontwikkelingen bevestigt dit.

Het tweede deel zoemt in op de spanningen, verschillen en conflicten tussen EU en EVRM-wetgeving en de jurisprudentie van de Luxemburgse en Straatsburgse rechters in de periode na de inwerkingtreding van het Verdrag van Lissabon. Hoofdstuk 3 verkent de nieuwe stand van zaken om in het bijzonder de impact te begrijpen die het nieuwe institutionele kader heeft op de relatie tussen het HvJEU en het EHRM. Het vergt een meer systematische benadering bij het onderzoeken van de veranderingen die de spanningen hebben veroorzaakt, met een bijzondere nadruk op Advies 2/13, alvorens de inhoudelijke uitspraken van de twee Europese hoven te bespreken. Het laat zien dat de post-Lissabon-periode wordt gekenmerkt door een aantal nieuwe ontwikkelingen in de jurisprudentie van het HvJEU. Het meest prominent zijn de bijna exclusieve focus op het Handvest, de scherpe daling in verwijzingen naar het EVRM en het negatieve Advies 2/13 over de toetreding van de EU tot het EVRM, die alle van invloed zijn geweest op de relatie met het Straatsburgse Hof, tot spanningen leidden en aanleiding gaven tot meer divergentie. In de hoofdstukken 4 en 5 worden de twee gebieden genoemd waarop de spanningen zich het duidelijkst hebben gemanifesteerd, namelijk de ruimte van vrijheid, veiligheid en rechtvaardigheid (RVVR), met de beginselen van wederzijds vertrouwen en wederzijdse erkenning, en het gebied van fundamentele sociale rechten. Deze twee hoofdstukken bieden een 
diepgaande analyse van de relevante jurisprudentie van de Straatsburgse en Luxemburgse hoven, die wijst op de onverenigbaarheden en bespreekt waarom en de mate waarin ze problematisch zijn.

Het centrale deel van dit boek is het derde deel, dat kritisch kijkt naar verschillende manieren waarop nationale rechters conflicten tussen EU- en EVRMrecht kunnen oplossen. Hoofdstuk 6 onderzoekt de verschillende conflictregels die voor de nationale rechters beschikbaar zijn wanneer zij proberen een oplossing te vinden voor een conflict tussen EU- en EVRM-recht. Het concludeert dat het internationale recht geen adequate regels biedt om conflicten tussen EU-recht en het EVRM op te lossen, vanwege hun speciale aard en status in het internationale recht. De enige regels die kunnen worden gebruikt, zijn die in de verdragen zelf. In dit verband is betoogd dat artikel 52, lid 3, van het EU-Handvest van de grondrechten, hoewel niet geschreven als een conflictregel, als zodanig kan worden beschouwd. Artikel 52 (3) van het Handvest bepaalt dat corresponderende Handvest- en EVRM-rechten dezelfde betekenis en reikwijdte hebben, terwijl de exacte betekenis en reikwijdte van de rechten van het Verdrag, overeenkomstig de toelichting bij deze bepaling, niet alleen wordt bepaald door de bewoordingen van de conventie, maar ook door de jurisprudentie van het Hof van Straatsburg. Wanneer er dus een conflict is tussen het EU-recht (dat moet worden geïnterpreteerd in het licht van het Handvest) en het EVRM, moet minstens dit laatste worden gevolgd. Het zevende en laatste hoofdstuk ontwikkelt verschillende scenario's aan de hand van uitspraken van nationale rechters om na te gaan op welke manieren zij tot nu toe met het probleem zijn omgegaan. Dit laatste hoofdstuk heeft een normatieve dimensie, en bespreekt niet alleen hoe nationale rechters met conflicten zijn omgegaan, maar ook hoe ze moeten omgaan met wat zij beschouwen als conflicten tussen hun verplichtingen krachtens EU-recht en krachtens het EVRM. Het eerste geïdentificeerde scenario is dat nationale rechter proberen conform te interpreteren. Sommige nationale rechters zullen zich namelijk tot het uiterste inspannen om te concluderen dat de jurisprudentie van de rechtbanken van Luxemburg en Straatsburg consistent is en een echt conflict dus voorkomen wordt. Conforme interpretatie kan echter ook problematisch zijn, omdat nationale rechters de uitkomst van de zaak als een conforme interpretatie kunnen presenteren, terwijl ze in feite de ene of de andere 
norm prioriteit geven. Het tweede scenario verwijst naar situaties waarin nationale rechters prioriteit geven aan het EVRM, zonder de vraag voor te leggen aan het HvJEU, ook al kan dit betekenen dat de EU-verplichtingen niet worden nagekomen. Als gevolg hiervan zou een staat te maken kunnen krijgen met inbreukprocedures wegens overtreding van de EU-recht. Het derde scenario bevat gevallen waarin nationale rechters besloten hebben om het conflict tussen EU- en EVRM-recht te herformuleren tot een conflict tussen EU-wetgeving en de nationale grondwet, dat vervolgens wordt geïnterpreteerd in het licht van het EVRM. Het vierde en laatste scenario betreft de verzending van de vragen om een prejudiciële beslissing betreffende de verenigbaarheid van EU-recht met het EVRM aan het HvJEU. Dit is aangewezen als een voorkeursscenario, maar alleen wanneer nationale rechters actief een dialoog aangaan met het HvJEU, waarbij de interpretatie van EU-recht ter discussie wordt gesteld, alsook de keuzes van het HvJEU in dat verband, en waarin zij hun eigen interpretatie van de bepalingen van EU-recht in het licht van het Handvest (dat vervolgens moet worden geïnterpreteerd in overeenstemming met het EVRM). Dit moet worden ondersteund door een verwijzing naar artikel 52, lid 3, van het Handvest, waarin duidelijk en overtuigend wordt gesteld dat overeenkomstige rechten op het Handvest en EVRM dezelfde betekenis en reikwijdte hebben. Daarom zou er nooit een onverenigbaarheid tussen de twee bronnen moeten zijn als de rechten overeenkomen (en dat doen ze in de meeste gevallen), omdat naleving van de minimumvereisten van het EVRM, zoals geïnterpreteerd door het EHRM, ook betekent overeenkomst met de primaire wet van de Europese Unie. 